\title{
ACCOUNTING POLICIES AND TREATMENTS OF CONTINGENT ASSETS AND LIABILITIES IN PUBLIC INSTITUTIONS
}

\author{
Iuliana Cenar ${ }^{1}$
}

\begin{abstract}
This paper aims to approach an issue that is less common in public institutions, namely the accounting policies and the accounting treatments of contingent assets and liabilities with the goal of sustaining the quality and completeness of financial accounting information, being a culture oriented towards the constant improvement of information quality, without limits to regulating prescriptions. The approached aspects are the following: the role of accounting policies, having as a reference system the accounting standards/rules and the professional reasoning; the need for specific accounting policies; the conceptualization and features of contingent assets and liabilities; the theoretical circumstances in which they are recognized, evaluated and presented in notes to the financial statements; the potential scenarios for the practical applicability of theoretical foundations regarding these probable, uncertain "elements" in public institutions.
\end{abstract}

Key words: contingent assets, contingent liabilities, accounting policies, probability, risk assessment

JEL Codes: $M 41$

\section{Introduction}

The basis for reference in the process of managing an entity's economic and financial activity is the information provided by financial statements. Although today there are multiple sources of information, the financial-accounting information continues to be the main way of reflecting the economic and financial activity and the results obtained by entities, both private and public. As a result of the uncertainties that are inevitable in the activities of public institutions, some of the component elements of financial statements are either probable or can't be accurately determined, but only estimated, as in the case of contingent/probable assets and liabilities.

\section{Research methodology}

In a time when the progress of informatics, of information technologies and of means of communication generate an information explosion in all areas, including the financial-accounting area, identifying an accounting system for investigation and which allows having something to say is a pretty difficult task. Subjects regarding internationalization, accounting standardization, institutional, administrative and accounting reform in the public sector have passed through the pen of those who are concerned by the science and art of the abstract representation of the economic reality. This is the background behind the decision to choose this subject: accounting policies and treatments of contingent assets and liabilities in public institutions.

The investigative approach was intended to be both theoretical and empirical, and the used research methods were: literature review, review of the legislative framework and of international accounting standards, comparison, observation, reasoning and extrapolation.

The objectives of this research are related to the analysis of: the theoretical and legal basis regarding contingent assets and liabilities, the convergences resulted from the process of adapting the Romanian private and public sectors to international norms, the discrepancies between theory and practice, possibility also generated by the discrepancies between the views of accounting

\footnotetext{
1 „1 Decembrie 1918” University, Faculty of Science, Alba Iulia, Romania,e-mail: cenar_iuliana@uab.ro
} 
theoreticians and practitioners; as well as the interferences between the international accounting rules that approach contingencies (IAS 37 and IPSAS 19), the national rules that regulate the organization and management of accounting for economic agents and public institutions (O.M.P.F. 3055/2009 and O.M.P.F. 1917/2005 with subsequent amendments and completions), the structure and content of financial statements prepared by these two categories of entities, the qualitative features of the accounting information, etc.

\section{Literature review}

The accounting information is placed at the center of objectivity and accuracy, but its starting points are two different and unequal sources in terms of quality. Thus, some information comes from transactions and events conducted during the financial year, being characterized by rigor and objectivity, and other information is recorded only at the end of the year, being the result of estimations and reflecting the accounting policies of the entity, whether it is private or public.

Accounting policies (including those developed for public institutions) stipulate how to reflect the effects of transactions and other events through recognition, selection of the evaluation base, derecognition and presentation of the elements in financial statements (Gîrbina, 2008).

Prudence has become a fundamental attitude in the accounting of any company; therefore we can talk about contingent assets and contingent liabilities in accounting (Georgescu I., 2005).

Aspects related to risk assessment, to using estimations, to the occurrence probability of events (i.e. contingent assets and liabilities), to accounting policies that refer to them are approached in literature by several authors, including: Ristea M., Feleagă N., Dutescu A, Cristea H., Popa A.F., Georgescu I., Bengescu M., Manolecu M., Roman A.G etc.

The perception regarding contingent assets and liabilities is not uniform, being susceptible to nuances.

Thus, "the approach (...) regarding contingent assets and liabilities wants to be a motivation for their reflection in the accounts of Class 8 - Special Accounts" (Ristea, 2009), which highlights the contingent rights and commitments that become certain or are cancelled following an event or the fulfilment of contractual clauses.

From a legal standpoint, contingent assets and liabilities are non-designated heritage assets, which is why they are not included in the assets or liabilities of the heritage, being recorded in offbalance sheet accounts, called also special accounts or accounts with intermediary function. These accounts are part of Class 8 of the Chart of Accounts (Bengescu M., 2006).

According to article 21, paragraph (1) of OMPF 3055/2009 for the approval of accounting regulations complying with European Directives, the off-balance sheet items include contingent assets (account 807 "Contingent Assets") and contingent liabilities (account 808 "Contingent Liabilities"), which is a fact that induces the idea that contingent assets and liabilities are not the same thing as the transactions reflected with the help of off-balance sheet accounts.

This last statement is also supported by M. Boulescu, who states that "off-balance sheet items include: entity;

- rights, obligations and goods that can't be integrated in the assets and liabilities of the

- contingent assets and liabilities".

The second place held by public institutions in the reforming accounting process justifies, at least partially, the absence of any reference to contingent assets and liabilities from the legal document that regulates the organization and management of their accounting (O.M.P.F. 1917/2005).

Regarding the off-balance sheet items, the mentioned legislative document states the following: "Accounts in group 80 - Off-balance sheet account - can be developed in terms of introducing specific accounts at the proposal of those institutions with the approval of the main 
credit release authority and of the Ministry of Public Finance". Obviously, this provision allows the use of accounts that reflect contingent assets and liabilities in public institutions.

Against this background, we ask ourselves: It is really necessary to disclose such items about public institutions?

Internationalization has inevitably affected the public sector and, implicitly, the perception of accounting. At international level, they issued international public sector accounting standards IPSAS, one of them, namely IPSAS 19 "Provisions, Contingent Liabilities and Contingent Assets", approaching the issue of defining, recognizing, assessing and presenting information about the contingent assets and liabilities.

The public sector accounting reform, conducted on the background of the management's orientation towards results and performance indicators in terms of the quality of public services and the satisfaction of citizens, forces us to take an approach that considers all the information valances of accounting, including those about uncertain and probable transactions and events: contingent assets and liabilities.

\section{Results and discussions}

\section{The need for specific accounting policies in public institutions}

An important source of information about the preparation of the financial statements of a public institution is represented by the accounting policies presented in the notes to the financial statements.

Naturally, there are several perceptions regarding accounting policies, among which are included: "specific databases that are permanently used by an organization when preparing financial statements (...), which are the most appropriate for the accurate presentation of its financial results and operations", "detailed methods of assessment, measurement and recognition (observation) chosen by an enterprise among those generally accepted by the law, accounting standards or commercial practices (Feleagă and Malciu, 2002)", "options determined by certain interests" (Ristea, 2000).

In the context of applying accounting rules and regulations to resolve the problems generated by the economic-financial reality, accounting policies are expressed in objective ways.

The specific practices adopted by a public institution when preparing and presenting financial statements is a component of accounting policies together with the principles, bases, conventions, rules and practices that have a similar role.

To recognize assets and liabilities in financial statements, an entity develops its own accounting policies. They aim to adapt the definitions and criteria for recognition of assets and liabilities to the real situations related to the activity of each public institution and to the specific situations that can arise during the course of their activity.

Professional reasoning is the one that intervenes in the absence of an IPSAS that is specifically applied to a transaction, event or condition. The head of the institution will make decisions regarding the development and implementation of an accounting policy that generates relevant and viable information for user to make decisions so that financial statements: accurately represent the financial position, performances and cash flows of the entity; reflect the economic substance of transactions in addition to their legal form; are neutral, cautious and complete.

To exercise professional judgment, the heads of public institutions should take into account the following sources, in descending order: (i) the provisions and guidance of international public sector accounting standards that approach similar issues; and (ii) the definitions, recognition and assessment criteria for assets, liabilities, revenues and expenses stipulated in the conceptual framework.

Pragmatically, accounting policies are developed and taken on by the head of the public entity, while in a regulated accounting, such as the one in Romanian public institutions, the 
responsibility for organizing and managing accounting belongs to the main credit release authority or to another person who has to obligation to manage that entity.

Among the fields of application of the accounting policies identified by Jean- François Casta stand out the following (Ristea, 2000): choosing the accounting methods and principles, choosing the presentation methods of financial statements, determining the volume of published information, inserting optional financial statements.

Thus, developing accounting policies includes opting between accounting methods, which may be structured as follows: accounting measurements and evaluation methods; methods for keeping track and organizing control documents and control procedures and for validating accounting entries; methods for summarizing, preparing and presenting financial statements; methods for measuring and assessing costs and analytical results (cost control, orientation of decision-making).

The users must be able to compare the financial statements of a public institution for a certain period of time in order to check the trends of its financial position, its performances and its cash flows necessary for various activities. For this, one must use the same accounting policies that will be adopted for each year (the principle of permanent methods).

A change in accounting policies should be implemented only if it's stipulated by an IPSAS or if such a change leads to a more adequate presentation of the events and transactions included in the financial statements of the public institution.

Changing the accounting policy refers to changing the accounting treatment, the recognition and evaluation of a transaction, event or condition within an evaluation basis.

Accounting policies may be general (they refer to the substance of financial organization and reporting: recognition, classification, evaluation, materiality) and specific (they refer to the particularities associated to specific categories of assets and liabilities, including those contingent).

Therefore, contingent assets and liabilities are subject to specific accounting policies and are demanded by the principle of prudence, by the need to improve communication of quality, transparent and competent information. Prudence means finding those accounting estimates associated with conditions of uncertainty, which don't overestimate assets and revenues and don't underestimate liabilities and expenses. In other words, prudence requires making value judgments, anticipating future events and values in conditions of uncertainty and taking discriminatory action on the basis of forecasts.

In our opinion, including contingent assets and liabilities in the accounting policies of public entities means: attention to detail, the supremacy of professional reasoning against omissions made by accounting regulations, adapting to the permanent remodeling of economic reality.

\section{Semantics of contingencies}

According to DEX, among the numerous meanings of the word "contingent" are also included: coincidental, accidental, occasional, sporadic, which may or may not be; which may or may not happen.

In accounting, the concept of contingent is used to name those liabilities and assets that are not recognized because their existence will be confirmed only by the occurrence or non-occurrence of one or more uncertain future events not wholly within the control of the public entity.

Thus, the concept of contingent refers to future events whose occurrence/non-occurrence is uncertain and can't be controlled by the enterprise. "The best way to look at a contingent liability is as an unlikely provision or as another unlikely debt".

In practice, by "probable" it is usually understood that an event will occur with a probability of over $50 \%$ or that it's more likely to happen than not to happen. Quantifying the occurrence probability of a contingent event is not mandatory; instead, it is recommended to recognize an estimated commitment when it is more probable than improbable. (Cristea et.al., 2004) 


\section{Contingent assets - accounting perception and approach}

According to IPSAS 19 "Provisions, contingent liabilities and contingent assets", a contingent asset is a possible asset that arises from past events and whose existence will be confirmed only by the occurrence or non-occurrence of one or more uncertain future events not wholly within the control of the entity.

The generating elements of contingent assets are usually unplanned or unexpected events that are not wholly within the control of the entity and give rise to the possibility of an inflow of economic benefits or service potential to the entity.

Given the meanings of assets and liabilities, "reflecting them in financial statements takes into account the current value of the attached economic flows" (Georgescu, 2005)

Thus, the accounting treatment of contingent assets depends on the probability of future economic benefits. If the flow of economic benefits:

a) is not probable - no asset is recognized and there is no presentation of additional information;

b) is probable, but uncertain - no asset is recognized, but additional information is presented;

c) is certain - that asset is no longer contingent and its recognition becomes appropriate (Ulea, 2007).

To ensure the principle of prudence, which considers economic deficits as being probable, but not future surpluses, the contingent assets are not recognized in financial statements. This could lead to recognizing incomes that may never be realized. In the event that achieving an income is certain, the associated asset is no longer contingent and its recognition becomes appropriate.

A contingent asset is presented when an inflow of economic benefits is probable. To the extent that future events invalidate this probability, an item that was recognized in the past in financial statements has to be derecognized. Schematically, the correlation between economic benefits or service potential and recognition/derecognition is as follows:

$\begin{aligned} & \text { The inflows of economic benefits or service } \\ & \text { potential are certain }\end{aligned}$
$\begin{aligned} & \text { The inflows of economic benefits or service } \\ & \text { potential are uncertain (are probable) }\end{aligned}$

\section{Chart no. 1. Correlation between economic benefits or service potential and the recognition of assets}

Contingent assets are continuously evaluated in order to ensure the appropriate reflection of changes in financial statements. If the inflow of economic benefits or service potential becomes certain and the value of the asset can be measured with reliability, the asset and the corresponding revenue will be recognized in financial statements for the period when the changes occurred. If the inflow of economic benefits or service potential becomes probable, the entity will present the contingent asset. uncertain.

An example of contingent asset is a claim subjected to a legal battle whose outcome is

Thus, we assume the public institution $\mathrm{A}$ is suing public institution $\mathrm{B}$, the material compensations demanded by A being assessed to 19.800 lei. On the day of signing the financial 
statements, the lawyers of the public institutions believe there is a $90 \%$ chance that A will win this lawsuit.

For public institution A, the financial statements will present a contingent asset until the final decision will be issued and the material compensations will be cashed in. At that moment, the contingent asset becomes a certain asset. The motivation of the public institution A to present the contingent asset is as follows: there is no commitment, the output of economic benefits in not probable (because lawyers think the entity will win the lawsuit) even if the asset can be measured with reliability.

When the inflow of economic benefits or service potential is probable, the public institution has to submit a brief description of the nature of the contingent asset at the reporting date and, if possible, to submit an estimation of the financial effect. Obviously, there is the issue of the reasonable expectation that those assets will generate benefits for the entity because there is no requirement to present these pieces of information about all the contingent assets.

Example: In September of year N, public institution A took to court public institution B and demanded compensations in the amount of 19.800 lei due to poor services. At the end of the financial year, the court had not issued a final sentence, but the lawyers believed the lawsuit will be won by the plaintiff, who will receive the requested amount from the defendant.

The disclosure of contingent assets should avoid giving misleading indications about the possibility of generating incomes. For example, a contingent asset would arise from a contract whereby a public entity allows a company in the private sector to extract minerals from one of its properties in exchange of paying the fees calculated on the basis of a price established by ton after the company began mining. In addition to disclosing the nature of the contract, the contingent asset should be quantified for the cases when a reasonable estimation can be made for the quantity that will be extracted and for the timing of the cash inflow. If there are no proven reserves or if other circumstances show the unlikelihood of the mining, the public entity would not present the information because there is no probable inflow of benefits (International Public Sector Accounting Standards Manual, p. 599).

\section{Delimitations and references regarding contingent liabilities}

According to IPSAS 19 "Provisions, contingent liabilities and contingent assets", the contingent liability is defined as follows:

- a possible obligation that arises from past events and whose existence will be confirmed only by the occurrence or non-occurrence of one or more uncertain events not wholly within the control of the entity; or

- a present obligation that arises from past events but is not recognized because:

a. it is not probable that on outflow of resources embodying economic benefits or service potential will be required to settle the obligation; or

b. the amount of the obligation cannot be measured with sufficient reliability.

A contingent liability also arises in the rare event that there is an obligation that can't be recognized because it can't be properly assessed (Ristea M. p. 151).

Provisions, being uncertain in terms of timing or amount, are also contingent, but are recognized as liabilities because they represent current obligations and it's probable to need an outflow of resources that incorporate the economic benefits or service potential.

For contingent liabilities, the recognition criteria of the liabilities mentioned previously are not met. The following chart shows the correlation between current or potential obligations and recognition of a liability. 


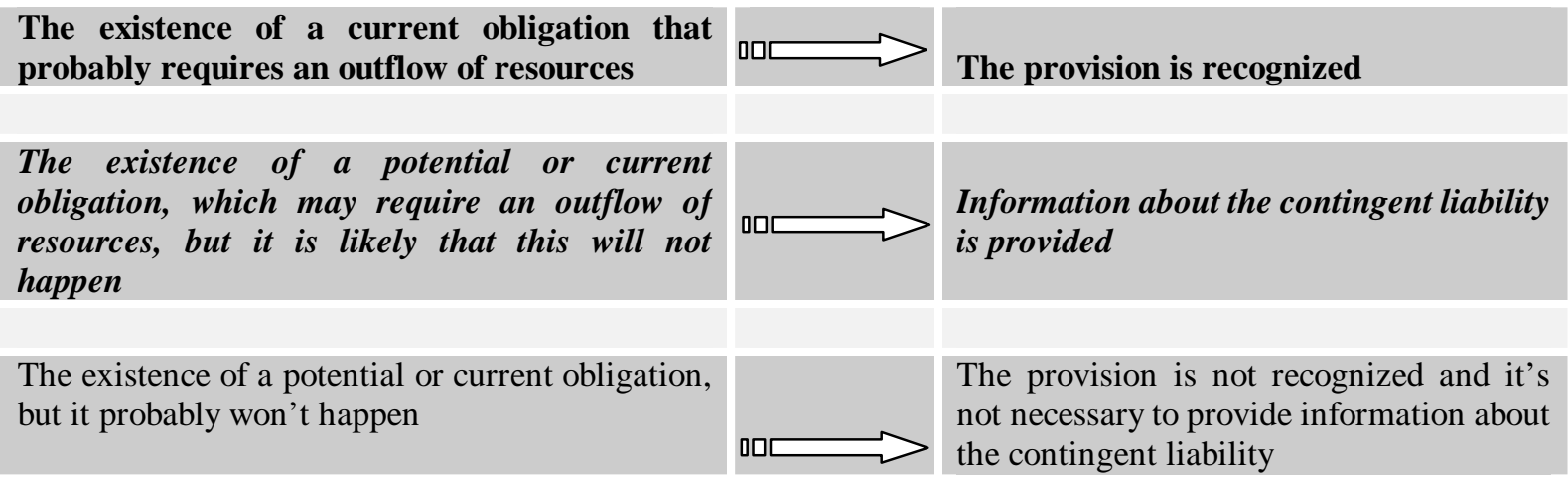

\section{Chart no. 2. Correlation between current or potential obligations and recognition of liabilities}

The difference between a provision and a contingent liability is related to probability. Thus, if a future obligation is more likely to occur than not to occur, then it is recognized as a provision, but if the situation is reverse, it is disclosed as a contingent liability (Cristea et.al., 2004)

Contingent liabilities are presented in the notes to the financial statements, unless the probability of having an outflow of resources that incorporate economic benefits or service potential is very low.

Contingent liabilities should be continuously assessed to determine if an outflow of resources that incorporate economic benefits or service potential has become probable. In this case, the provision will be recognized in the financial statements for the period when the changed occurred.

For example, a local public entity may have violated the law regarding the environment, but it's unclear if there really was a negative impact over the environment. When it becomes clear that there have been environmental damages and remedies are demanded, the entity will recognize the provision because the outflow of economic benefits is now probable.

For all the classes of contingent liabilities, at the reporting date, an entity should present a brief description of the contingent liability's nature, as well as the following:

- an estimation of the financial effects;

- an indication of the uncertainty level related to the amount and timing of the outflow of resources;

- the possibility of a reimbursement.

As mentioned previously, the exception to this presentation is given by the situation when there is a remote possibility of occurrence of an outflow of resources.

Example 1. In September of year $\mathrm{N}$, a public institution (the Town Hall) is sued by a company because the services provided by the institution (protection and security) were deficient. The company seeks compensation in the amount of 30.000 lei.

- At the end of year $\mathrm{N}$, it is estimated that there is a $35 \%$ probability to lose the lawsuit;

- $\quad$ By the end of year $\mathrm{N}+1$, the lawsuit is still ongoing and the probability of losing was estimated at $43 \%$

- $\quad$ In the year $\mathrm{N}+2$, the losing probability increased to $75 \%$

- In the year N+3, new evidence was accepted, which by the end of the year lead to the probability of losing the trial to drop to $15 \%$.

At the end of the trial, the court ruled that the public institution has to pay damages in the amount of 14.000 lei. 


\section{Presentation of information:}

- Because the probability to lose the lawsuit is small, on 12.31.N the institution will recognize a contingent liability in the notes to the financial statements in the amount of 10.500 lei $(30.000 \times 35 \%)$.

- On 12.31.N+1, the probability to lose the trial increased to $57 \%$ compared to the chance to lose it, so the notes to the financial statements will include a contingent liability of 12.900 lei at the end of the financial year.

- On 12.31.N+2, the probability to lose the lawsuit increased significantly; therefore, the public institution will recognize a provision of 22.500 lei in its financial statements.

- On 31.12. N+3, the institution will resume the provision previously established in the amount of 18.000 lei.

\subsection{0 lei.}

- After the final ruling, the institution will record the payment of damages in the amount of

Example 2. A public institution guarantees a loan for an entity that provides public services. The entity had a good financial situation at the moment of the loan guarantee.

Thus, we presume that a public institution offers guarantees in the year $\mathrm{N}$ for a local authority that contracted a loan in the amount of 18.000 lei for several investment projects for a period of 4 years. The guarantor is solidity with the local public authority, and if the latter defaults, the public institution has to assume the debt. The financial statements presented by the local public authority reveal that the amount that has to be reimbursed is 120.000 lei, plus interest in the amount of 40.000 lei.

At the end of the year when the public institution offered guarantees, the notes to the financial statements will disclose a contingent liability in the amount of 160.000 lei for the remaining amount plus interest (unless the probability for an outflow of resources is very small).

The disclosure of the contingent liability is based on the following aspects: offering the guarantee is the event that generates the current obligation, the outflow of economic benefits or potential service is not probable to occur at the end of the year.

In case the financial situation of the entity will deteriorate in the following year and the entity demands protection from its creditors, the public institution has to recognize a provision because it is probable than an outflow of resources materialized in economic benefits or service potential will occur.

\section{Conclusions}

The accounting policies must be integrated within the general policies of each public institution with legal personality, which include policies regarding the organization, analysis and processing of supporting documents, audit policies, policies regarding internal control, etc. In turn, accounting policies include general and specific policies, which also comprise policies regarding contingent assets and liabilities.

Contingent assets and liabilities are part of a category of accounting information that is the result of estimations. They are a way to record the probabilities and uncertainties in accounting. Their existence (of probabilities and uncertainties) is recognized by exercising prudence in preparing and presenting financial statements.

It is found that, in general, lawsuits are the subject of contingencies and they have a high risk of difficulty, requiring estimations from lawyers and legal advisers on the probability and effects induced by such events.

In this case, public institutions must analyze and present in a separate section of the notes to the financial statements the contingent assets/liabilities, namely the generating events, as well as the estimations regarding the event that will transform them into balance sheet items. 
Public institutions in our country are "probably" reluctant to present information about contingent assets and contingent liabilities in the notes to the financial statements because they believe this is inadequate. But, in theory, there are extremely rare cases when disclosing such information brings substantial prejudices to the position of the public entity that is in a dispute with other parties, whose subject is a contingent asset or liability.

Could this be the real reason (although, in these circumstances, one should present the general nature of the lawsuit together with pieces of evidence and the reasons why the information wasn't disclosed)?

\section{References}

1. Bengescu M., 2006. Puncte de vedere privind contabilitatea activelor şi datoriilor contingente (Views on the Accounting of Contingent Assets and Contingent Liabilities), http://steconomice.uoradea.ro/anale/volume/2006/finante-contabilitate-si-banci/40.pdf (10.08.2011), pp. 245.

2. Boulescu M., 2006. Auditul elementelor extrabilanţiere (The Audit of Off-Balance Sheet Items), Tribuna Economica Publishing House, Bucharest, pp. 49.

3. Cristea H., et. al., 2004. Ghid pentru înţelegerea şi aplicarea Standardelor Internaționale de Contabilitate. Provizioane, datorii şi active contingente (Guide to Understanding and Applying International Accounting Standards. Provisions, Contingent Liabilities and Contingent Assets), CECCAR Publishing House, Bucharest, pp.22, 37, 51.

4. Dutescu A., 2003. Politici contabile de întreprindere (Enterprise Accounting Policies), CECCAR Publishing House, Bucharest.

5. Feleagă N., Malciu L., 2002. Politici şi opțiuni contabile (Accounting Policies and Options), Economică Publishing House, Bucharest, pp. 13.

6. Georgescu I., 2005. Active si pasive eventuale, http://anale.feaa.uaic.ro/anale/resurse/ 15\%20Georgescu\%20I-Active\%20si\%20pasive\%20eventuale.pdf (17.08.2011), pp. 115, 119.

7. Girbină, M.M., Bunea St., 2008. Sinteze, studii de caz şi teste grilă privind aplicarea IAS IFRS (revizuite)(Summaries, Case Studies and Tests regarding the application of IAS IFRS (revised)), vol. III CECCAR Publishing House, Bucharest, pp. 136.

8. Ristea, M., 2000. Metode şi politici contabile de întreprindere (Enterprise Accounting Methods and Policies), Tribuna economică Publishing House, Bucharest, pp. 16, 19, 20.

9. Ristea, M., et.al., 2009.Contabilitatea societăţilor comerciale (The Accounting of Companies), Universitara Publishing House, Bucharest, pp. 165.

10. Popa A.F., at. al., 2007. Studii practice privind aplicarea Standardelor Internaționale de Raportare Financiara în România (Practical Studies on the Application of International Financial Reporting Standards in Romania), Contaplus Publishing House, Ploiesti.

11. Ulea N.M., 2007. Teorie contabila si raportare financiara privind activele si datoriile intreprinderii (Accounting Theory and Financial Reporting regarding the Assets and Liabilities of the Enterprise), $\mathrm{PhD}$ thesis, www.biblioteca.ase.ro/downres.php?tr=886, pp. 12.

12. International Federation of Accountants (2009). International Accounting Standards Guidebook for the Public Sector, CECCAR Publishing, Bucharest, pp. 599.

13. The order of the Ministry of the Public Finance no. 3055/2009, for the approval of accounting regulations compliant with European Directives, published in Official Gazette no. 766 bis/ 2009 with the following changes and. 
14. The order of the Ministry of the Public Finance no. 1917/2005 for the approval of the Methodological norms regarding the organization and the management of the accounting of the public institutions patrimony, of the accounts plan for the public institutions and the monograph regarding the registration in accounting of the main operations, Official Gazette no 1186bis/ 2005, with the following changes and.

15. http://www.contabilul.manager.ro/a/3565/provizioane-active-contingente-si-datorii-contingente.html

16. http://www.accounting-leader.ro/articole/ifrs/ias-37-provizioane-datorii-si-active-contingente/8 